\title{
Anticancer effects of an extract from the scallop Patinopecten yessoensis on MCF-7 human breast carcinoma cells
}

\author{
CHU LEE $^{1 *}$, WONJOO CHUN $^{2 *}$, RONGJIE ZHAO $^{3}$, YOUNG DAE KIM $^{1}$, MYUNG MO NAM $^{1}$, \\ DAE HWA JUNG ${ }^{4}$, IL JE CHO ${ }^{5}$, KYUNG HWAN JEGAL $^{5}$, TAE HOON LEE ${ }^{6}$, YOUNG WOO KIM ${ }^{5}$, \\ SANG MI PARK ${ }^{5}$, SEONG A. JU ${ }^{7}$, CHUL WON LEE ${ }^{2,5}$, SANG CHAN KIM ${ }^{5}$ and WON G. AN ${ }^{2,8}$ \\ ${ }^{1}$ Aquaculture Industry Division, NFRDI, Gangneung 210-809; ${ }^{2}$ Institute of Marine Biotechnology, Pusan National \\ University, Busan 609-735, Republic of Korea; ${ }^{3}$ School of Mental Health, Qiqihar Medical University, Qiqihar, \\ Heilongjiang 161042, P.R. China; ${ }^{4}$ HaniBio Co., Ltd., Gyeongsan 712-260; ${ }^{5}$ MRC-GHF, College of Korean Medicine, \\ Daegu Haany University, Gyeongsan 38610; ${ }^{6}$ Department of Biological Sciences, College of Biomedical Sciences and \\ Engineering, Inje University, Gimhae 621-749; ${ }^{7}$ School of Biological Sciences, University of Ulsan, Ulsan 680-749; \\ ${ }^{8}$ Division of Pharmacology, School of Korean Medicine, Pusan National University, Yangsan 626-870, Republic of Korea
}

Received February 18, 2016; Accepted March 3, 2017

DOI: $10.3892 / 01.2017 .6424$

\begin{abstract}
Patinopecten yessoensis, is a species of scallop and a marine bivalve mollusk. In traditional East Asian medicine, scallop meat is used as a drug for the treatment of diabetes, pollakisuria, and indigestion. The present study was conducted in order to examine the potential anticancer effects of scallop flesh extract (SE) on MCF-7 human breast cancer cells. An MTT assay was used to evaluate cell viability and flow cytometry was used for the assessment of cell cycle distribution and apoptosis. The alteration in protein expression level was determined by western blot analysis, and the amounts of docosahexaenoic acid and eicosapentaenoic acid in the SE were measured by gas chromatography. SE inhibited the growth of MCF-7 human breast cancer cells in a dose-dependent manner by inducing G0/G1 phase arrest. The cell cycle arrest was associated with the upregulation of p53 and p21, and downregulation of G1 phase-associated cyclin D1/cyclin-dependent kinase (Cdk) 4 and cyclin E1/Cdk 2. In addition, SE-mediated cell cycle arrest was associated with the promotion of apoptosis, as indicated by the expression of apoptosis-associated proteins and changes in nuclear morphology. SE appeared to induce the mitochondrial
\end{abstract}

Correspondence to: Dr Won G. An, Division of Pharmacology, School of Korean Medicine, Pusan National University, 49 Pusandaehak Street, Yangsan 626-870, Republic of Korea E-mail:wgan@pusan.ac.kr

Dr Sang Chan Kim, MRC-GHF, College of Korean Medicine, Daegu Haany University, 1 Haanydae Street, Gyeongsan 38610, Republic of Korea

E-mail: sckim@dhu.ac.kr

*Contributed equally

Key words: scallop, cell cycle, apoptosis, human breast cancer apoptotic cascade, as indicated by a decreased expression of Bcl-2, activation of Bcl-2 associated X protein, release of cytochrome $c$, decrease in procaspase-3, and an increase in cleaved-poly (ADP-ribose) polymerase (PARP). Furthermore, the expression levels of Fas-associated via death domain and cleaved caspase- 8 were increased in a SE dose-dependent manner. Taken together, these results suggest that the intrinsic and extrinsic pathways of apoptosis are associated with the anticancer effects of SE on MCF-7 cells. Thus, SE may be a suitable candidate for the treatment and prevention of human breast cancer.

\section{Introduction}

Patinopecten yessoensis, a species of scallop, is a marine bivalve mollusk from the pectinidae family. It is a cold-tolerant species that predominately inhabits coastal waters of the northern Korean peninsula and islands of Japan. In traditional East Asian medicine, the flesh of scallops was used as a drug for the treatment of diabetes, pollakisuria, and indigestion $(1,2)$.

Breast cancer is an escalating global public health concern associated with a high mortality rate (3). Breast cancer was predicted to account for 232,670 (29\%) of all new cancer cases and cause 40,000 (15\%) of all cancer-related mortalities of women in the US during 2014 (4).

Chemoprevention has received increasing attention as an approach for breast cancer prevention. It entails the use of natural or synthetic antioxidants to prevent or delay cancer progression (5). The $\mathrm{G} 1$ phase of the cell cycle is regulated by a balance of factors, including the critical regulatory components, cyclin D, cyclin E, cyclin-dependent kinases (Cdks) and cyclin-Cdk inhibitor proteins (6). Cell cycle progression and Cdk activity are inhibited by Cdk inhibitors (CKIs), including p21 and p18, which inactivate Cdk-cyclin complexes to inhibit cell proliferation $(7,8)$. The p53 tumor suppressor protein is a major regulator of cell cycle progression during G1 phase, as its activation results in the upregulation of p21 (9-11). 
Apoptosis is the process of programmed cell death, which is critical for the homeostasis of multicellular organisms (12). In addition, it may eliminate malignant tumor cells without eliciting damage to normal cells (13). A variety of diseases, including cancer, may be triggered by abnormalities in apoptosis. Apoptosis may be induced via two major pathways: The extrinsic (death receptor) pathway and the intrinsic (mitochondrial) pathway $(14,15)$.

Mollusks are a rich reservoir of natural bioactive compounds, which may possess antitumor, antioxidant, and immunomodulatory activities (16); shellfish proteins are considered a major potential resource for the development of antitumor drugs (17). In particular, Sasaki et al (18) identified that the glycoprotein fraction from Patinopecten yessoensis extracts exhibited an antitumor activity in mice. However, the action and mechanism of scallop flesh extract (SE) on MCF-7 human breast cancer cells have yet to be elucidated. Therefore, the present study examined the antiproliferative effects of SE on MCF-7 cells. The results demonstrated that SE inhibited cell proliferation by cell cycle arrest at the G0/G1 phase, leading to apoptosis.

\section{Materials and methods}

Chemicals and antibodies. Antibodies to Bcl-2 and p53 were purchased from EMD Millipore (Billerica, MA, USA). An anti-p21 antibody was obtained from BD Biosciences (San Jose, CA, USA). Antibodies directed against Actin (cat. no. sc-58673), Bcl-2 associated X (Bax) (cat. no. sc-7480), Cdk2 (cat. no. sc-70829), and Cdk4 (cat. no. sc-136241) were obtained from Santa Cruz Biotechnology, Inc. (Dallas, TX, USA). The antibodies for cleaved caspase- 8 (cat. no. 8592) and -9 (cat. no. 7237), procaspase-3 (cat. no. 12742), poly (ADP-ribose)-polymerase (PARP) (cat. no. 9532), cleaved-PARP (cat. no. 5625), cyclin D1 (cat. no. 2922), cyclin E1 (cat. no. 20808), cytochrome $c$ (cat. no. 4272), and Fas-associated via death domain (FADD) (cat. no. 2782) were purchased from Cell Signaling Technology, Inc. (Danvers, MA, USA). Horseradish peroxidase-conjugated secondary antibody (cat. no. sc-51625) was obtained from Santa Cruz Biotechnology, Inc. DAPI, propidium iodide (PI), MTT, docosahexaenoic acid (DHA), eicosapentaenoic acid (EPA), and all other chemicals were purchased from Sigma-Aldrich (Merck KGaA, Darmstadt, Germany).

Preparation of SE. Mature scallops were captured from the sea near the East Sea Fisheries Research Institute (Gangneung, South Korea). Extraction was performed using a standard extraction process: Briefly, $50 \mathrm{~g}$ of scallop flesh was immersed in 1:1 methanol, sonicated for $30 \mathrm{~min}$ and allowed to stand for $48 \mathrm{~h}$. The obtained extract was filtered through No. 20 Whatman filter paper (GE Healthcare Life Sciences, Chalfont, UK), evaporated under reduced pressure using a vacuum evaporator (Eyela; Tokyo Rikakikai Co., Ltd., Tokyo, Japan) and lyophilized using a freeze dryer (Labconco, Kansas City, MO, USA). Finally, $2.31 \mathrm{~g}$ of lyophilized powder was obtained (yield, 4.62\%). A sample of the lyophilized powder was deposited at the Division of Pharmacology, School of Korean Medicine, Pusan National University, Korea (deposition no. MH2013-006).
Gas chromatographic analysis of fatty acids in scallop flesh. A set of standards containing 37 mixtures of fatty acid methyl esters from Supelco (Sigma-Aldrich; Merck KGaA,) were prepared for analysis by dissolving in isooctane to a concentration of $100 \mathrm{mg} / \mathrm{ml}$. The total lipid in scallop flesh $(10 \mathrm{~g})$ was extracted with a Soxhlet extractor and $200 \mathrm{ml}$ of ether. The extracted lipid $(25 \mathrm{mg})$ was saponified with $2 \mathrm{ml}$ of methanolic $\mathrm{NaOH}(0.5 \mathrm{M})$ solution by refluxing $5 \mathrm{~min}$ at $100^{\circ} \mathrm{C}$. Once cooled to room temperature, $2 \mathrm{ml}$ of $14 \%$ boron trifluoride-methanol solution was added and the sample was boiled for $2 \mathrm{~min}$. The sample was again cooled to room temperature and $1 \mathrm{ml}$ of isooctane was added. Sodium sulfate $(1 \mathrm{~g})$ was added and the mixture was agitated to eliminate residual water. The upper isooctane layer was used for gas chromatography analysis. EPA and DHA concentrations were determined by gas chromatography (GC-2010, Shimadzu Corporation, Kyoto, Japan) equipped with a flame ionization detector (FID) and a SP-2560 capillary column (100 m length, $0.25 \mathrm{~mm}$ inner diameter, $0.22 \mu \mathrm{m}$ film thickness; Sigma-Aldrich, Merck KGaA). The operating conditions were as follows: The initial temperature was $100^{\circ} \mathrm{C}$, which was increased by $3^{\circ} \mathrm{C}$ per min until the temperature was $240^{\circ} \mathrm{C}$. The detector and injector temperatures were 250 and $210^{\circ} \mathrm{C}$, respectively. DHA and EPA were identified by comparing their retention time with a mixture of standard fatty acids.

Cell culture. MCF-7 human breast cancer cells were purchased from the Korean Cell Line Bank (Seoul, Korea). The cells were cultured in Dulbecco's modified Eagle's medium supplemented with $10 \%$ fetal bovine serum (Hyclone; GE Healthcare Life Sciences, Logan, UT, USA) and $1 \%$ penicillin/streptomycin (Invitrogen; Thermo Fisher Scientific, Inc.), and maintained in a humidified incubator with $5 \% \mathrm{CO}_{2}$ at $37^{\circ} \mathrm{C}$.

MTT assay. In order to determine cytotoxic concentrations of SE, MCF-7 human breast cancer cells were plated in a 96-well plate at a density of $2.5 \times 10^{4}$ cells per well. The cells were incubated for $24 \mathrm{~h}$, followed by treatment with $0.5,1$ or $2 \mathrm{mg} / \mathrm{ml}$ of SE. The cells were then incubated for the next $24 \mathrm{~h}$ at $37^{\circ} \mathrm{C}$ in an incubator with $5 \% \mathrm{CO}_{2}$. Following the incubation of the cells, viable cells were stained with $0.5 \mathrm{mg} / \mathrm{ml} \mathrm{MTT}$ for $4 \mathrm{~h}$ at $37^{\circ} \mathrm{C}$. The medium was removed from the cells, and formazan crystals produced in the wells were dissolved with the addition of $200 \mu \mathrm{l}$ dimethylsulfoxide. Absorbance was measured at $595 \mathrm{~nm}$ using a microplate reader (Bio-Rad Laboratories, Inc., Hercules, CA, USA). Cell viability was defined as relative to untreated control cells.

DAPI staining. MCF-7 human breast cancer cells were grown on 96-well plates for $24 \mathrm{~h}$, then treated with SE $(0.5,1$ or $2 \mathrm{mg} / \mathrm{ml}$ ) for $24 \mathrm{~h}$ as described by Zhang et al (19) with minor modifications. The treated cells were washed with PBS and fixed with $1 \%$ paraformaldehyde solution for $20 \mathrm{~min}$ at room temperature. The solution was eliminated and the fixed cells were washed with PBS, followed by incubation with DAPI solution for $10 \mathrm{~min}$ at room temperature. Fluorescence images were observed in a dark room using a confocal microscope (LSM700; Carl Zeiss AG, Oberkochen, Germany).

Annexin V and PI staining. Detection of apoptotic cells was performed using a Muse ${ }^{\mathrm{TM}}$ Annexin V and Dead Cell kit (EMD 
Millipore). Briefly, the plated MCF-7 human breast cancer cells were treated with SE as previously described. Suspended cells were collected and adherent cells were trypsinized. The cells were harvested through centrifugation at $500 \mathrm{x}$ g for $5 \mathrm{~min}$ at $4^{\circ} \mathrm{C}$. After washing with PBS, the cells were resuspended in the binding buffer and stained with Annexin $\mathrm{V}$ and PI. The proportion of apoptotic cells was quantified using FACS (FACSCanto II, BD Biosciences, Franklin Lakes, NJ, USA).

Flow cytometry analysis of the cell cycle. MCF-7 human breast cancer cells were seeded in $100 \mathrm{~mm}$ dishes. Following $24 \mathrm{~h}$ of SE exposure, the cells were trypsinized, harvested through centrifugation $\left(500 \mathrm{x} \mathrm{g}, 5 \mathrm{~min}, 4^{\circ} \mathrm{C}\right)$ and fixed in $70 \%$ ethanol. The cells were resuspended and incubated with RNase $(250 \mu \mathrm{g} / \mathrm{ml}$, final concentration) for $30 \mathrm{~min}$ and stained with PI (10 $\mu \mathrm{g} / \mathrm{ml}$, final concentration) for $1 \mathrm{~h}$. Flow cytometry was performed with FACS, and analysis was performed with the associated CellQuestPro software (BD Biosciences).

Western blot analysis. SE-treated MCF-7 human breast cancer cells were collected by centrifugation $(500 \mathrm{x} \mathrm{g}$, $5 \mathrm{~min}, 4^{\circ} \mathrm{C}$ ) and washed once with PBS. Washed cell pellets were resuspended in extraction lysis buffer $[50 \mathrm{mM}$ 4-(2-hydroxyethyl)-1-piperazineethanesulfonic acid ( $\mathrm{pH} 7.0$ ), $250 \mathrm{mM} \mathrm{NaCl}, 5 \mathrm{mM}$ EDTA, $0.1 \%$ Nonidet P-40, $1 \mathrm{mM}$ phenylmethane sulfonyl fluoride, $0.5 \mathrm{mM}$ dithiothreitol, $5 \mathrm{mM} \mathrm{NaF}$ and $0.5 \mathrm{mM}$ sodium orthovanadate] containing $5 \mu \mathrm{g} / \mathrm{ml}$ each of leupeptin and aprotinin and incubated for $20 \mathrm{~min}$ at $4^{\circ} \mathrm{C}$. Microcentrifugation $(16,000 \mathrm{x} \mathrm{g}, 10 \mathrm{~min}$, $4^{\circ} \mathrm{C}$ ) was performed for removal of cell debris, followed by rapid freezing of the supernatants. A protein assay reagent (Bio-Rad Protein Assay kit II; catalog no. 5000002; Bio-Rad Laboratories, Inc.) was used to determine protein concentration, according to the manufacturer's protocol. Total cellular protein from treated or untreated cell extracts $(30 \mu \mathrm{g})$ was separated with $10 \%$ SDS-PAGE and electroblotted onto nitrocellulose membranes, followed by incubation overnight with blocking solution ( $5 \%$ skimmed milk) at $4{ }^{\circ} \mathrm{C}$, and then with a primary antibody (1:1,000 dilution) for $2 \mathrm{~h}$. Blots were then washed three times with Tween 20/Tris-buffered saline (TTBS), incubated with a 1:1,000 dilution of horseradish peroxidase-conjugated secondary antibody for $1 \mathrm{~h}$ at room temperature and washed three times with TTBS again. Enhanced chemiluminescence (ECL) western blotting detection reagents (GE Healthcare Life Sciences, Chalfont, UK) were used for the development of blots. The bands were visualized by WesternBright ECL HRP substrate (Advansta, Inc. Menlo Park, CA, USA) and developed by Kodak film (Kodak, Rochester, NY, USA). Quantification of band densities was performed using ImageJ software (version 1.6.0_20; National Institutes of Health, Bethesda, MD, USA).

Statistical analysis. Experiments were performed independently $\geq 3$ times and values were expressed as the mean \pm standard deviation. Multiple comparison tests were performed for different dose groups. The Levene's test was used for examination of variance homogeneity. If the Levene's test indicated no significant deviations from variance homogeneity, the obtained data were analyzed using an independent t-test and a one way analysis of variance test followed by the least-significant differences multi-comparison test to
Table I. Content of DHA and EPA in SE samples analyzed by gas chromatography $(n=3)$.

\begin{tabular}{lr}
$\omega-3$ polyunsaturated fatty acid & Content $(\mathrm{mg} / 100 \mathrm{~g})$ \\
\hline DHA & $665.2 \pm 0.01$ \\
EPA & $1,177.1 \pm 0.06$
\end{tabular}

Values are expressed as the mean \pm standard deviation following three independent experiments. DHA, docosahexaenoic acid; EPA, eicosapentaenoic acid.

determine which pairs of the group comparison were significantly different. Statistical analysis was performed using SPSS software (version 14.0; SPSS, Inc., Chicago, IL, USA). P<0.05 was considered to indicate a statistically significant difference.

\section{Results}

Gas chromatography analysis of SE. The profiles of DHA and EPA in SE were determined using gas chromatography (Fig. 1 and Table I). Validation with a set of 37 standards verified the reliability and stability of the method, and use of the method resulted in successive separation of DHA and EPA in SE samples.

Effects of SE on MCF-7 cell proliferation and cell cycle arrest. The antiproliferative effects of SE on human breast cancer were investigated in the MCF-7 breast cancer cell line. As demonstrated by the data in Fig. 2A, SE significantly inhibited the proliferation of MCF-7 cells in a dose-dependent manner ( 0.5 and $1 \mathrm{mg} / \mathrm{ml} \mathrm{SE}, \mathrm{P}<0.01 ; 2 \mathrm{mg} / \mathrm{ml} \mathrm{SE}, \mathrm{P}<0.001)$. In addition, the DNA contents of MCF-7 cells treated with SE were examined using flow cytometry cell cycle distribution analysis. Treatment with SE induced a dose-dependent accumulation of MCF-7 cells in the G0/G1 phase. In particular, the accumulation of cells in the G0/G1 phase was significantly increased at the concentrations of 1 and $2 \mathrm{mg} / \mathrm{ml}$, compared with the control group (1 and $2 \mathrm{mg} / \mathrm{ml} \mathrm{SE}, \mathrm{P}<0.05$; Fig. 2B and C).

Effect of SE on proteins involved in the cell cycle. The expression levels of p53 and p21 were investigated to determine their potential association with SE treatment. The results of a western blot assay showed that p53 expression was increasingly induced with increasing concentrations of SE, and p21 expression was correspondingly increased (p53: 0.5, 1 and $2 \mathrm{mg} / \mathrm{ml} \mathrm{SE}, \mathrm{P}<0.001$; p21: $0.5 \mathrm{mg} / \mathrm{ml} \mathrm{SE}, \mathrm{P}<0.05 ; 1 \mathrm{mg} / \mathrm{ml}$ $\mathrm{SE}, \mathrm{P}<0.01 ; 2 \mathrm{mg} / \mathrm{ml} \mathrm{SE}, \mathrm{P}<0.001$; Fig. $3 \mathrm{~A}$ ). In addition, treatment with $\mathrm{SE}$ resulted in a significantly decreased expression of cyclins D1 and E1, and Cdks 2 and 4, in a dose-dependent manner, compared with the control group (cyclins D1: 0.5 and $1 \mathrm{mg} / \mathrm{ml} \mathrm{SE}, \mathrm{P}<0.01 ; 2 \mathrm{mg} / \mathrm{ml} \mathrm{SE}, \mathrm{P}<0.001$; cyclins E1: 0.5 and $1 \mathrm{mg} / \mathrm{ml} \mathrm{SE}, \mathrm{P}<0.01 ; 2 \mathrm{mg} / \mathrm{ml} \mathrm{SE}, \mathrm{P}<0.001$; Cdk 4: 0.5 and $1 \mathrm{mg} / \mathrm{ml} \mathrm{SE}, \mathrm{P}<0.01 ; 2 \mathrm{mg} / \mathrm{ml} \mathrm{SE}, \mathrm{P}<0.001$; Cdk 2: 0.5, 1 and $2 \mathrm{mg} / \mathrm{ml} \mathrm{SE}, \mathrm{P}<0.001$; Fig. $3 \mathrm{~B}$ and $\mathrm{C}$ ).

Apoptosis is induced by SE in MCF-7 cells. DAPI staining and a confocal microscope were used to examine the morphological 

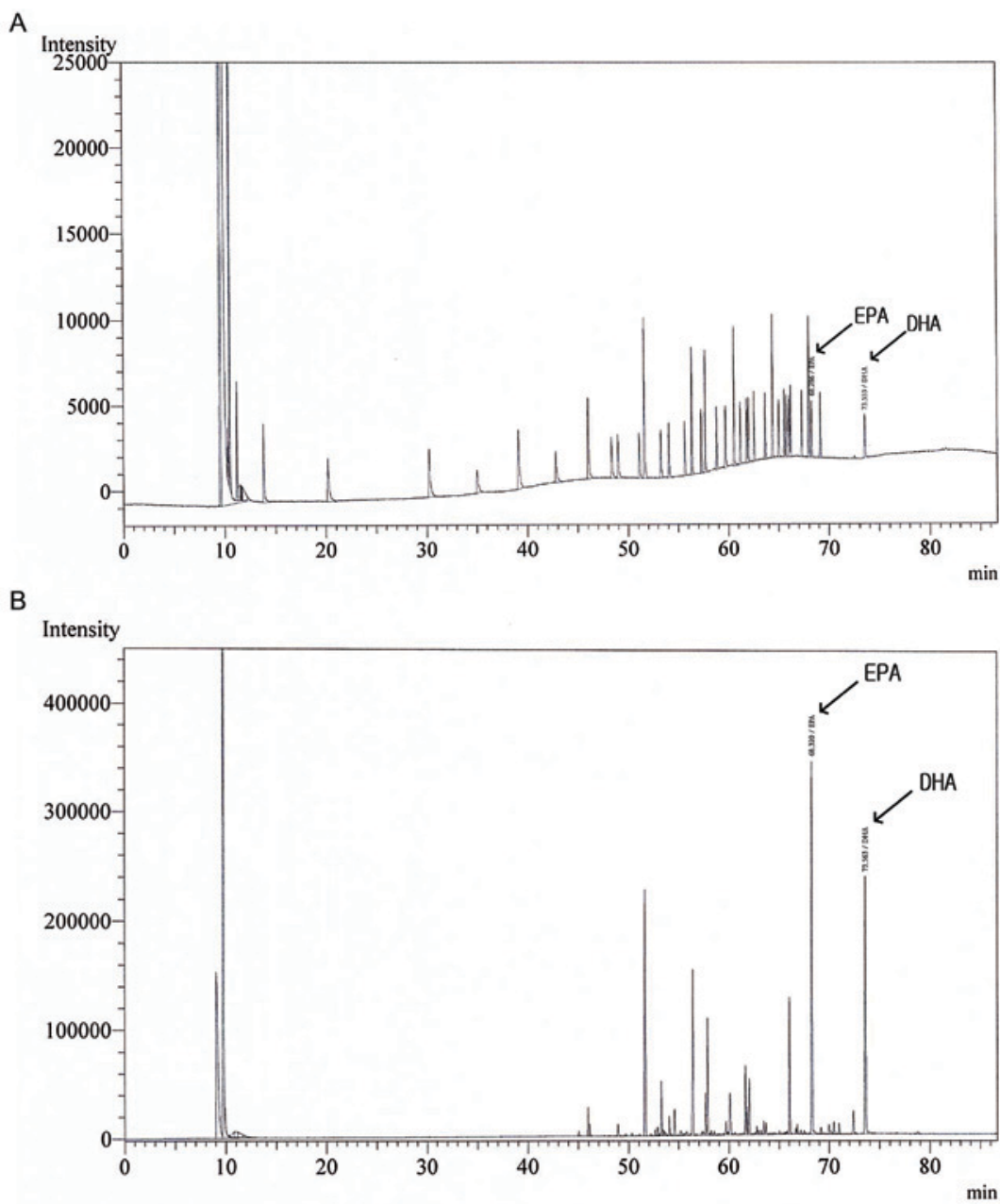

Figure 1. Gas chromatograms. (A) Gas chromatogram of 37 commercial standard compounds. (B) Gas chromatogram of the two marker compounds in scallop flesh extract, docosahexaenoic acid and eicosapentaenoic acid.

changes of MCF-7 cells treated with SE. The staining showed fragmented and condensed chromatin, characteristic of apoptotic cell death (Fig. 4A). In addition, in a flow cytometry experiment with Annexin V/PI staining, there were significant increases to the proportion of apoptotic cells at increasing concentrations of SE treatment $(0.5 \mathrm{mg} / \mathrm{ml} \mathrm{SE}, \mathrm{P}<0.05 ; 1 \mathrm{mg} / \mathrm{ml}$ $\mathrm{SE}, \mathrm{P}<0.01 ; 2 \mathrm{mg} / \mathrm{ml} \mathrm{SE}, \mathrm{P}<0.001$; Fig. 4B and C).

Regulation of Bcl-2 and Bax expression caused by SE in MCF-7 cells. Expression of Bcl-2 and Bax was examined using a western blot assay. The results indicated that treatment with SE suppressed the expression of Bcl-2, an anti-apoptotic protein, and increased the expression level of Bax, a pro-apoptotic protein, in a dose-dependent manner $(\mathrm{Bcl}-2: 0.5 \mathrm{mg} / \mathrm{ml}$ $\mathrm{SE}, \mathrm{P}<0.01 ; 1$ and $2 \mathrm{mg} / \mathrm{ml} \mathrm{SE}, \mathrm{P}<0.001$; Bax: $0.5 \mathrm{mg} / \mathrm{ml} \mathrm{SE}$, $\mathrm{P}<0.05 ; 1$ and $2 \mathrm{mg} / \mathrm{ml} \mathrm{SE}$; $\mathrm{P}<0.01$; Fig. 5).

Effects of SE on the expression levels of FADD, caspases, $P A R P$, and cytochrome $c$ in MCF-7 cells. The expression of FADD was increased in a dose-dependent manner as compared with the control group $(0.5 \mathrm{mg} / \mathrm{ml} \mathrm{SE}, \mathrm{P}<0.05 ; 1$ and $2 \mathrm{mg} / \mathrm{ml} \mathrm{SE}, \mathrm{P}<0.01$; Fig. 6A). In addition, involvement of caspases in apoptosis induction of SE was evaluated. The expression of procaspase-3, cleaved caspase- 8 , and cleaved caspase-9 was also examined by a western blot assay (Fig. 6A and B). Our results showed that treatment with SE resulted in a significantly decreased expression of procaspase-3 (0.5 and $1 \mathrm{mg} / \mathrm{ml} \mathrm{SE}, \mathrm{P}<0.01 ; 2 \mathrm{mg} / \mathrm{ml} \mathrm{SE}, \mathrm{P}<0.001$; Fig. 6A) and an increased expression of cleaved caspase-8, cleaved caspase-9, and cleaved PARP in a dose-dependent manner as compared with the control group (cleaved caspase-8: 0.5 and $1 \mathrm{mg} / \mathrm{ml} \mathrm{SE}, \mathrm{P}<0.01 ; 2 \mathrm{mg} / \mathrm{ml} \mathrm{SE}, \mathrm{P}<0.001$; cleaved caspase-9: $0.5 \mathrm{mg} / \mathrm{ml} \mathrm{SE}, \mathrm{P}<0.05 ; 1 \mathrm{mg} / \mathrm{ml} \mathrm{SE}, \mathrm{P}<0.01$; $2 \mathrm{mg} / \mathrm{ml} \mathrm{SE}, \mathrm{P}<0.001$; cleaved PARP: 0.5 and $1 \mathrm{mg} / \mathrm{ml} \mathrm{SE}$, $\mathrm{P}<0.05 ; 2 \mathrm{mg} / \mathrm{ml} \mathrm{SE}, \mathrm{P}<0.001$; Fig. $6 \mathrm{~A}$ and $\mathrm{B})$. Treatment with $\mathrm{SE}$ resulted in the activation of caspase-3, -8 , and -9 , as demonstrated by the increase in cleaved caspase- $3,-8$, and -9 levels, leading to a significant increase in the levels of cleaved PARP in MCF-7 cells. Furthermore, the expression of cytochrome $c$ was analyzed to examine whether cytochrome $c$ had been released from mitochondrial membrane. The results indicated that the amount of cytochrome $c$ was significantly increased by SE, in a dose-dependent manner, compared with the control group (cytochrome $c: 0.5$ and $1 \mathrm{mg} / \mathrm{ml} \mathrm{SE}, \mathrm{P}<0.01 ; 2 \mathrm{mg} / \mathrm{ml} \mathrm{SE}, \mathrm{P}<0.001$; Fig. 6B).

Effects of DHA and EPA on proliferation and protein expression levels of p53, p21 and PARP in MCF-7 cells. The 


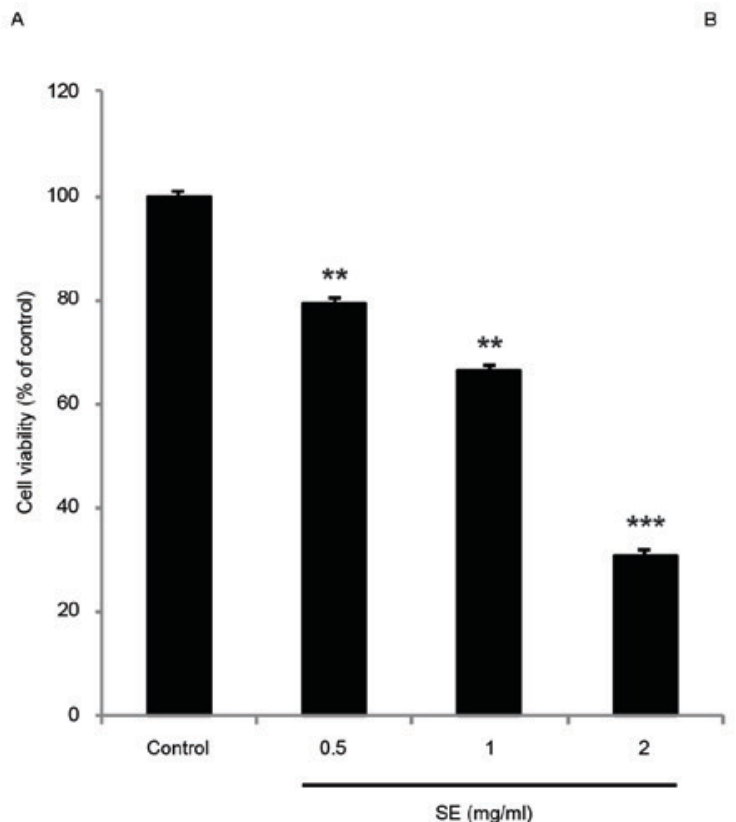

C

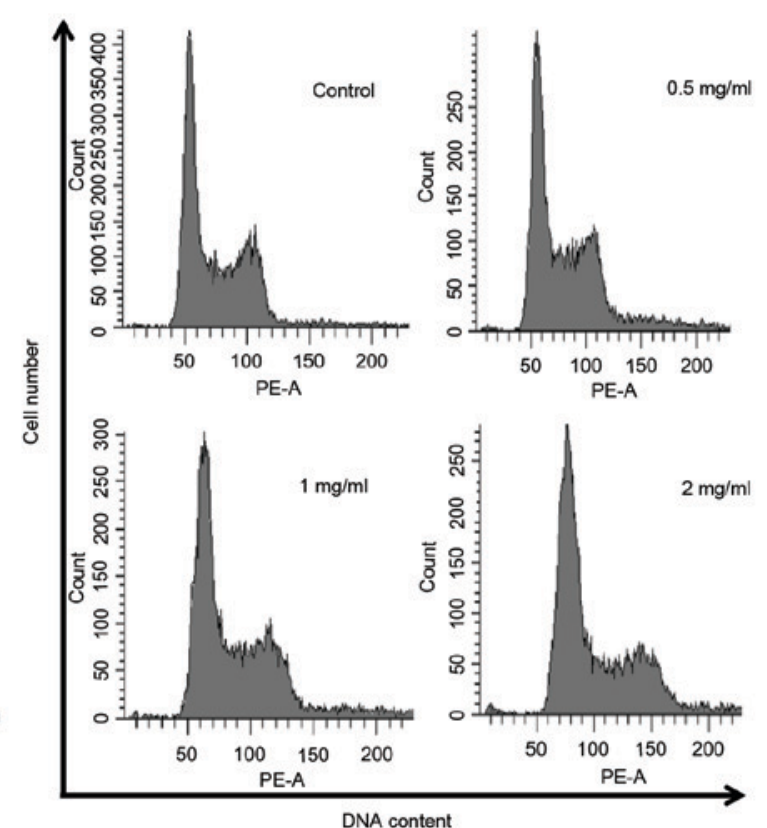

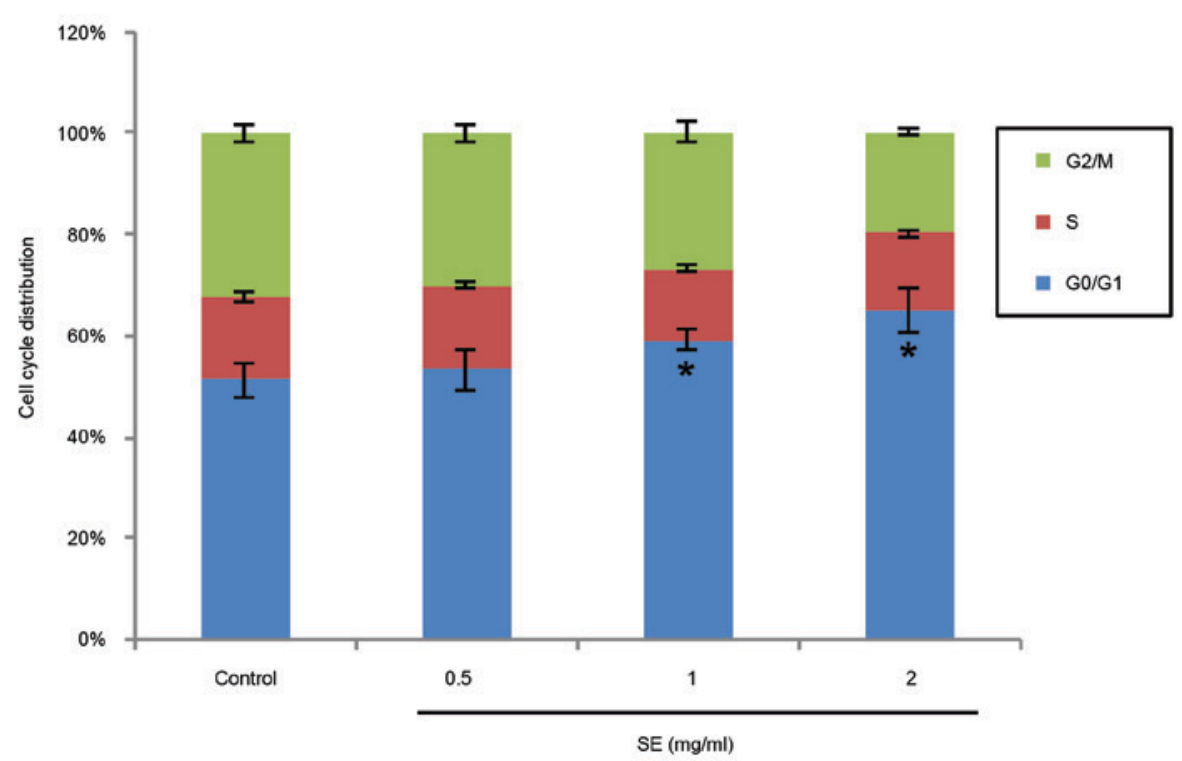

Figure 2. Effects of SE on proliferation and cell cycle arrest in MCF-7 cells. Cells $\left(5 \times 10^{5}\right.$ cells $\left./ \mathrm{ml}\right)$ were treated with various concentrations $(0-2 \mathrm{mg} / \mathrm{ml})$ of SE for 24 h. (A) Cytotoxic effects of SE on MCF-7 cells were quantified using an MTT assay. (B) Cells were fixed, stained with PI and analyzed for cell cycle distribution with flow cytometry following treatment with SE at the indicated concentrations. (C) The percentage of cells in the G0/G1, S and G2/M phases from the flow cytometry of (B) is presented. Data present the mean \pm standard deviation from three independent experiments. ${ }^{*} \mathrm{P}<0.05,{ }^{* *} \mathrm{P}<0.01$ and ${ }^{* * * *} \mathrm{P}<0.001$ vs. control group. SE, scallop flesh extract; PI, propidium iodide.

antiproliferative effects of DHA and EPA on human breast cancer were examined by using MCF-7 cells. As shown in Fig. 7A, DHA or EPA significantly inhibited the proliferation of MCF-7 cells, in a dose-dependent manner, at the concentrations of 20,30 and $40 \mu \mathrm{M}$ compared with the control group (20, 30 and $40 \mu \mathrm{M}$ DHA, $\mathrm{P}<0.001 ; 20 \mu \mathrm{M}$ EPA, $\mathrm{P}<0.01 ; 30$ and $40 \mu \mathrm{M}$ EPA, $\mathrm{P}<0.001)$. Alterations to the expression of p53, p21 and PARP were then examined to determine the regulatory effects of DHA or EPA. The results of a western blot analysis indicated that $\mathrm{p} 53$ was significantly induced by a $40-\mu \mathrm{M}$ concentration of DHA or EPA $(\mathrm{P}<0.001)$. p2 1 was also significantly increased at a $40-\mu \mathrm{M}$ concentration of DHA or EPA compared with the control group $(\mathrm{P}<0.001$ for DHA; P<0.05 for EPA, Fig. 7B). Moreover, the level of cleaved PARP was also significantly increased at $40 \mu \mathrm{M}$ of DHA or EPA compared with the control group $(\mathrm{P}<0.001$, Fig. 7C).

\section{Discussion}

In traditional East Asian medicine, the scallop flesh was commonly used as a drug for the treatment of diabetes, pollakisuria, and indigestion (1). Shellfish proteins are also considered a potential resource for antitumor drug development (17). However, the molecular action and mechanism of inhibitory effects of SE on MCF-7 human breast cancer cells 
$\mathbf{A}$

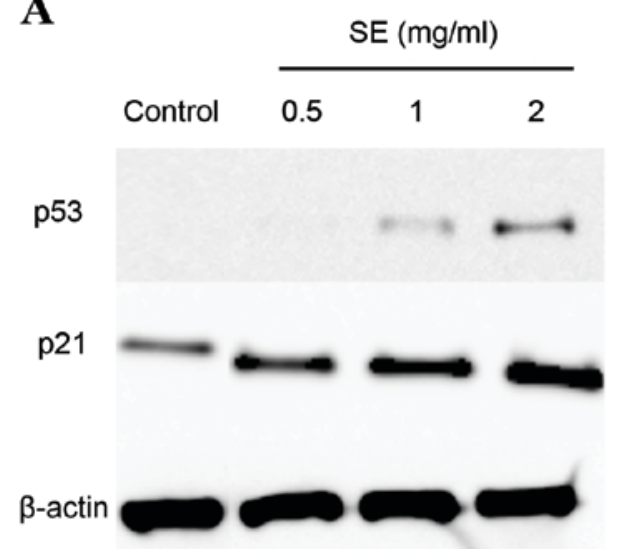

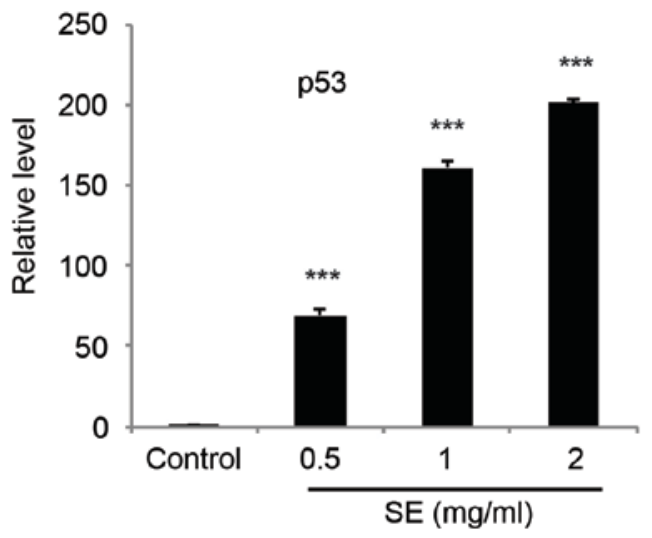

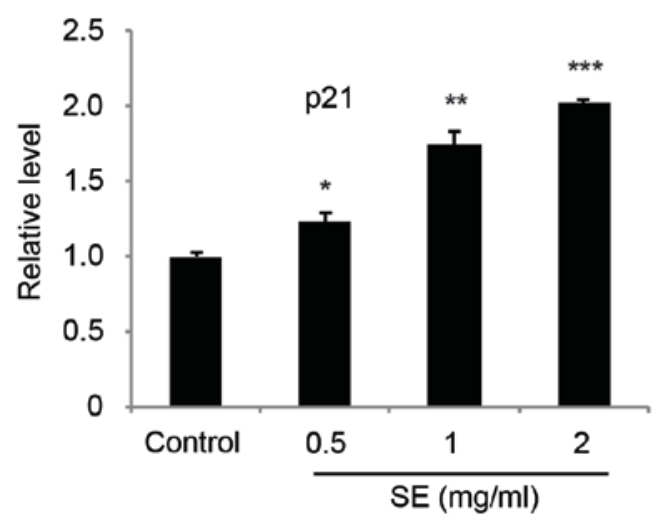

B
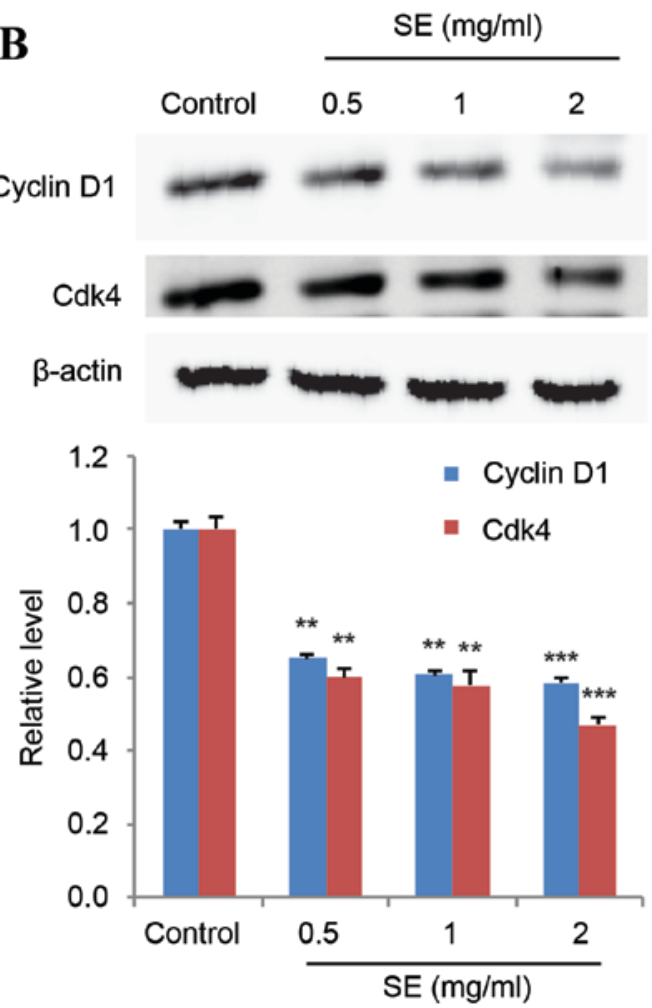

C
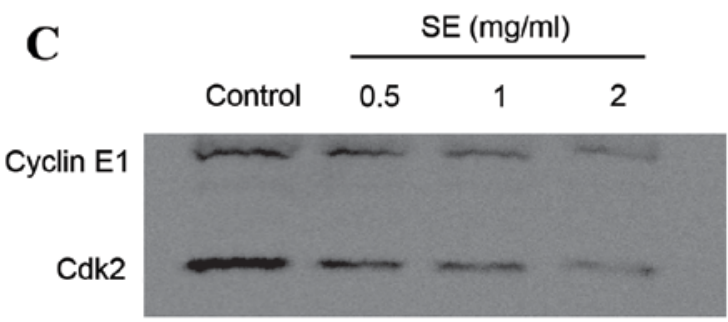

$\beta$-actin

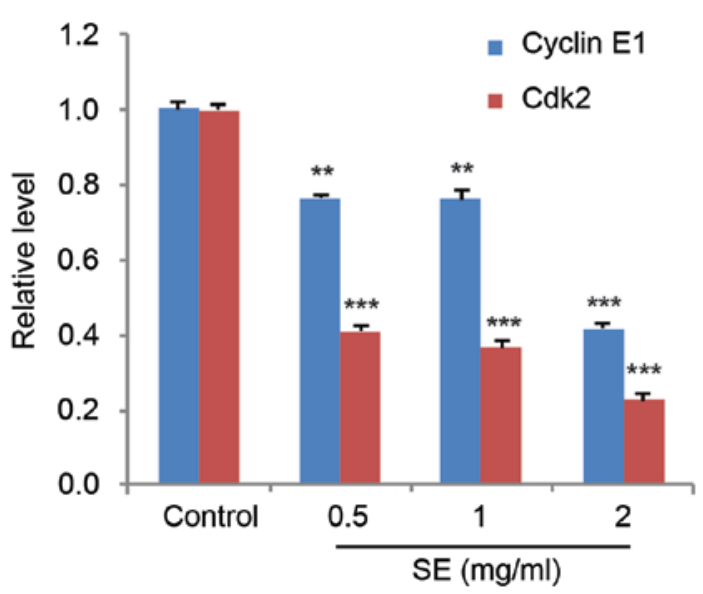

Figure 3. Effects of SE on proteins involved in the cell cycle. The cells were treated with the indicated concentrations of SE for 24 h. A western blot analysis was performed for the determination of the relative protein levels of (A) p53 and p21, (B) cyclins D1-CDK 4 and (C) cyclin E1-CDK2. $\beta$-actin was used as a loading control. The blots included in the fig. are representative of three blots that yielded similar results. The relative levels of each protein vs. $\beta$-actin were quantified. Data present the mean \pm standard deviation from three independent experiments. ${ }^{*} \mathrm{P}<0.05,{ }^{* *} \mathrm{P}<0.01$ and ${ }^{* * * *} \mathrm{P}<0.001$ vs. control group. SE, scallop flesh extract; CDK, cyclin-dependent kinase.

have not been elucidated. Therefore, the present study investigated the antiproliferative effects of SE on MCF-7 cells.
Cancerous cells commonly exhibit a high rate of growth, due to deregulation of the apoptosis and cell cycle 
A

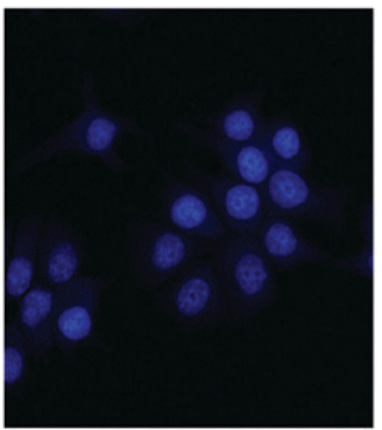

Control

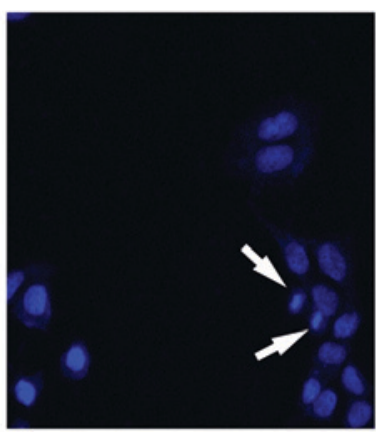

$0.5 \mathrm{mg} / \mathrm{ml}$

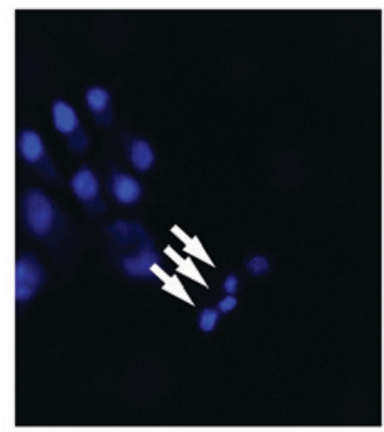

$1 \mathrm{mg} / \mathrm{ml}$

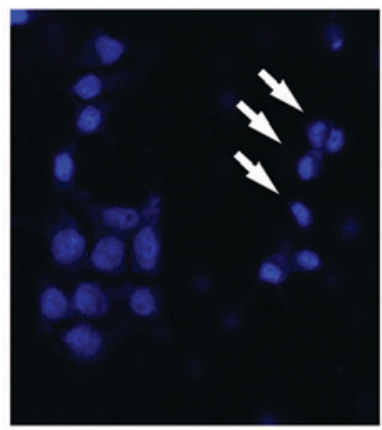

$2 \mathrm{mg} / \mathrm{ml}$

B
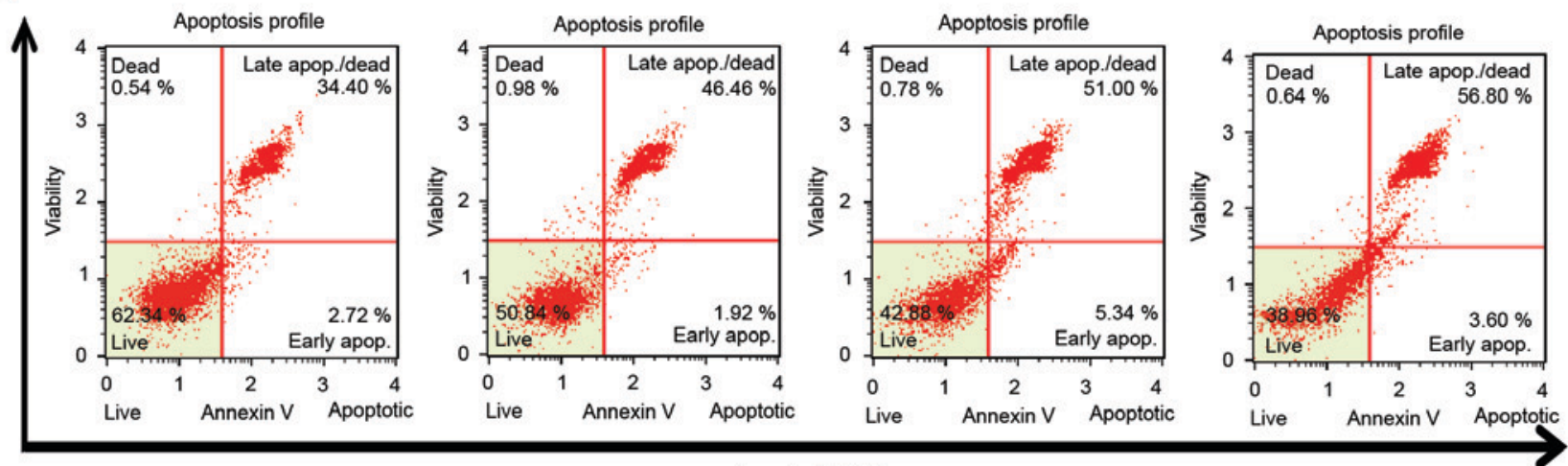

Annexin-V-FITC

C

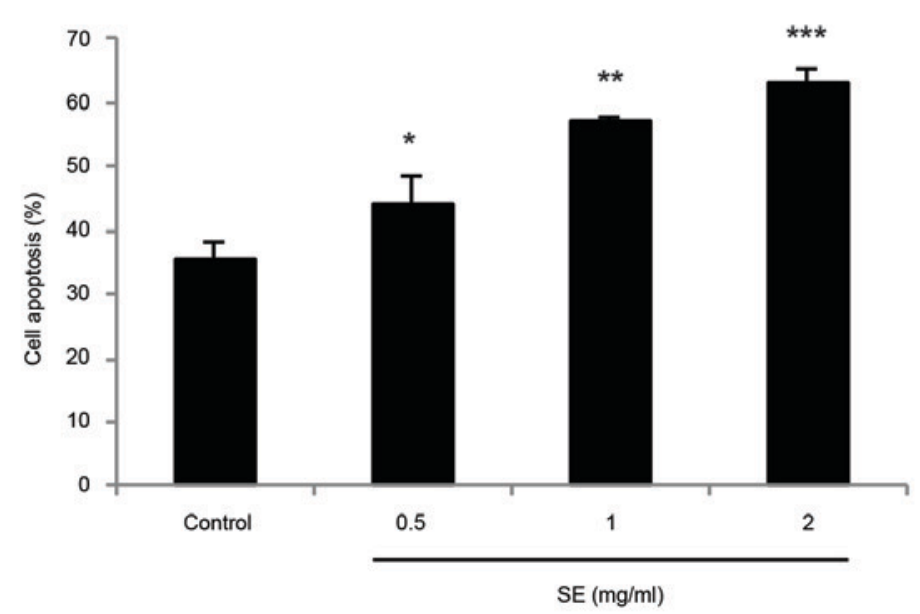

Figure 4. SE-induced apoptosis in MCF-7 cells. (A) Fluorescent micrographs of SE treated and untreated cells with DAPI staining. The white arrows indicate apoptotic cells. (B) Flow cytometry analysis of SE-induced apoptosis in MCF-7 cells. (C) Statistical analysis of the extent of apoptosis from (B). Data present the mean \pm standard deviation from three independent experiments. ${ }^{*} \mathrm{P}<0.05,{ }^{* *} \mathrm{P}<0.01$ and ${ }^{* * *} \mathrm{P}<0.001$ vs. control group. SE, scallop flesh extract; FITC, fluorescein isothiocyanate.

pathways (8). Accordingly, the induction of cell cycle arrest is considered to be a therapeutic target in cancer (20-22). The present study has demonstrated that SE significantly inhibited the proliferation of MCF-7 cells in a dose- dependent manner. In addition, treatment with SE induced a dose-dependent accumulation of MCF-7 cells in the G0/G1 phase of the cell cycle. In particular, the accumulation of cells was significantly increased compared with the control group at the concentrations of 1 and $2 \mathrm{mg} / \mathrm{ml}$. These results suggest that the inhibitory effect of SE on MCF-7 breast cancer cell proliferation may be associated with the induction of cell cycle arrest in the G0/G1 phase.
The p53 tumor suppressor gene serves a major role in mediating the response of cells to diverse stressors by repressing or inducing various genes involved in apoptosis, cell cycle arrest, and DNA repair (10,23-26). In addition, p53 induces the transcription of a variety of genes, including p21, an important CKI and regulator of the cell cycle. The induction of p21 results in the inhibition of cyclin-Cdk complexes and cell cycle arrest $(7,8,20,27,28)$. The cyclin-Cdks complexes control cell cycle progression; their inactivation causes cell cycle arrest (20). The results from the present study revealed that p53 was induced, and p21 was correspondingly increased, following treatment with SE in a dose-dependent manner. 


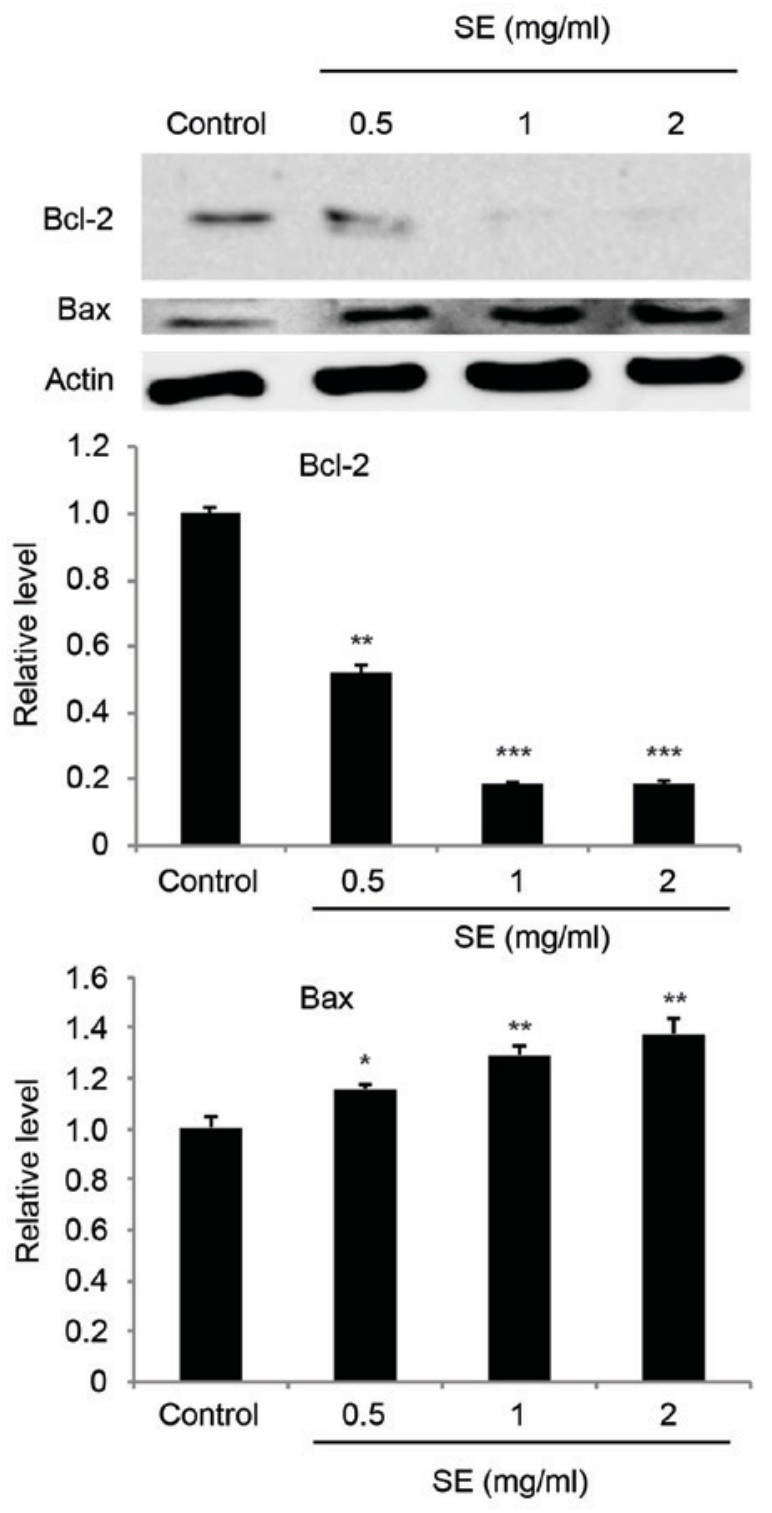

Figure 5. The effects of SE on expression of Bcl-2 and Bax in MCF-7 cells. Cells were treated with the indicated concentrations of SE for $24 \mathrm{~h}$. Western blot analysis was performed for determination of protein levels of Bcl-2 and Bax. $\beta$-Actin was used as a loading control. The blot included in the fig. is representative of three blots yielding similar results. The relative levels of each protein vs. $\beta$-actin were quantified. Data present the mean \pm standard deviation from three independent experiments. ${ }^{*} \mathrm{P}<0.05,{ }^{* *} \mathrm{P}<0.01$ and ${ }^{* * *} \mathrm{P}<0.001$ vs. control group. SE, scallop flesh extract; Bax, Bcl-2 associated $\mathrm{X}$.

Furthermore, treatment with SE resulted in a significant, dose-dependent decrease in the expression of cyclins D1 and E1, and Cdks 2 and 4, compared with the control group. These data indicate that treatment with SE affected G0/G1 cell cycle checkpoints via these proteins to cause a block to cell cycle progression.

Caspases, cysteine-class aspartyl-specific proteases, are indicated as inactive precursors (procaspases) that require proteolytic cleavage for activation (29-33). In apoptosis, this process proceeds via activation of the intrinsic mitochondrial pathway or the extrinsic death receptor pathway (34-36). The intrinsic pathway involves the regulation of $\mathrm{Bcl}-2$ family members (including $\mathrm{Bcl}-2$ and $\mathrm{Bax}$ ), the release of cytochrome $c$ and the subsequent activation of caspases (including caspase-3, -7 and -9) (37-40). The extrinsic pathway involves transmembrane death receptors that bind to pro-apoptotic ligands and cause the subsequent activation of caspases (including caspase-3, -7 and -8) (40,41). The results of the present study demonstrated that treatment with SE suppressed the expression of Bcl-2 (an anti-apoptotic protein) and increased the expression levels of Bax (a pro-apoptotic protein) in a dose-dependent manner. Furthermore, the amount of cytochrome $c$ was significantly increased by SE in a dose-dependent manner. The decrease in Bcl-2, the increase in Bax and the release of cytochrome $c$ from the mitochondria into the cytosol may be caused by SE-induced intrinsic apoptosis. Further results from the present study indicated that treatment with SE significantly decreased the expression of procaspase-3, and increased the expression of cleaved caspase- 8 and -9 , FADD, and cleaved PARP in a dose-dependent manner. These results indicate that treatment with SE results in activation of caspase-3, -8 , and -9 , leading to a significant increase in the level of cleaved PARP in MCF-7 cells. Taken together, the results of the present study suggest that intrinsic and extrinsic pathways of apoptosis may be associated with the antiproliferative effects of SE on MCF-7 cells.

A number of studies have also reported on anticancer agents from the flesh of marine organisms (42-44). Previous studies have particularly focused on the antitumor effects of DHA and EPA (45-49). Dietary $\omega-3$ fatty acids have exhibited significant tumor-suppressing effects; DHA has been identified as the primary tumor-suppressing fatty acid (50). $\omega-3$ polyunsaturated fatty acids (DHA and EPA) may inhibit breast cancer growth via the activation of a neutral sphingomyelinase-mediated pathway and DHA has been demonstrated to synergistically enhance the cytotoxic activities of docetaxel in cancer cells via an increase in apoptosis $(51,52)$. EPA was also previously demonstrated to inhibit the liver metastasis of mouse MC-26 colorectal cancer cells injected into a mouse model through the inhibition of $\mathrm{PGE}_{2}$-dependent cell motility (53). The data of the present study demonstrated that DHA or EPA significantly inhibited the proliferation of MCF-7 cells in a dose-dependent manner at the concentrations 20, 30 and $40 \mu \mathrm{M}$, compared with the control group. A western blot analysis revealed that p53 and p21 were significantly induced at a $40-\mu \mathrm{M}$ concentration of DHA or EPA compared with the control group. In addition, the expression of cleaved PARP was also significantly increased at a $40-\mu \mathrm{M}$ concentration of DHA or EPA compared with the control group. By utilizing gas chromatographic analysis, the present study has demonstrated that DHA and EPA are the most prominent markers of SE. Taking all of the data together, we hypothesize that the antiproliferative effect of SE on MCF-7 human breast cancer cells is caused by DHA and EPA.

In conclusion, the results demonstrate that $\mathrm{SE}$ induced a growth inhibition of MCF-7 human breast cancer cells, in a dose-dependent manner, by inducing G0/G1 phase arrest. In addition, the cell cycle arrest was associated with the upregulation of p53 and p21, and the downregulation of G1 phase-associated cyclin D1-Cdk 4 and cyclin E1-Cdk2 complexes. SE-mediated cell cycle arrest was also linked with promotion of apoptosis, as demonstrated by the expression of apoptosis-related proteins and changes to nuclear morphology. 
A
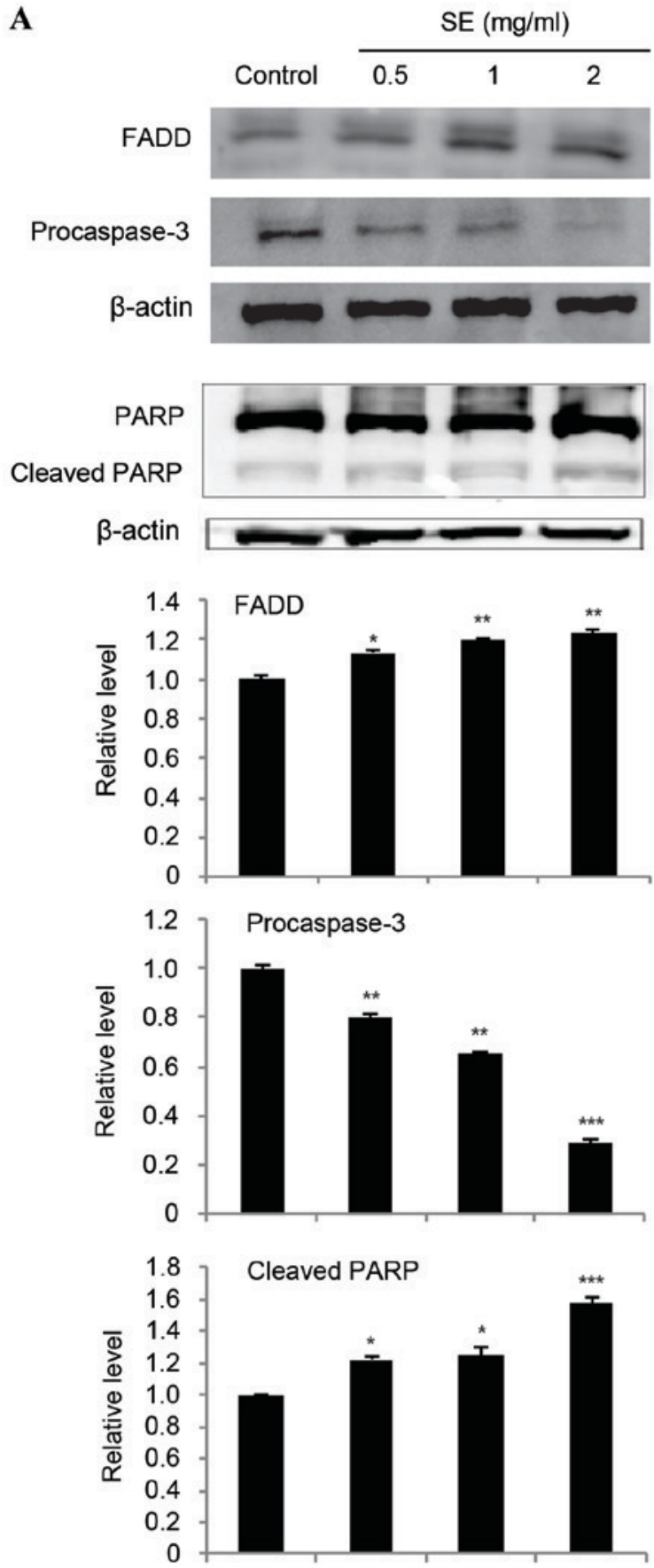

B
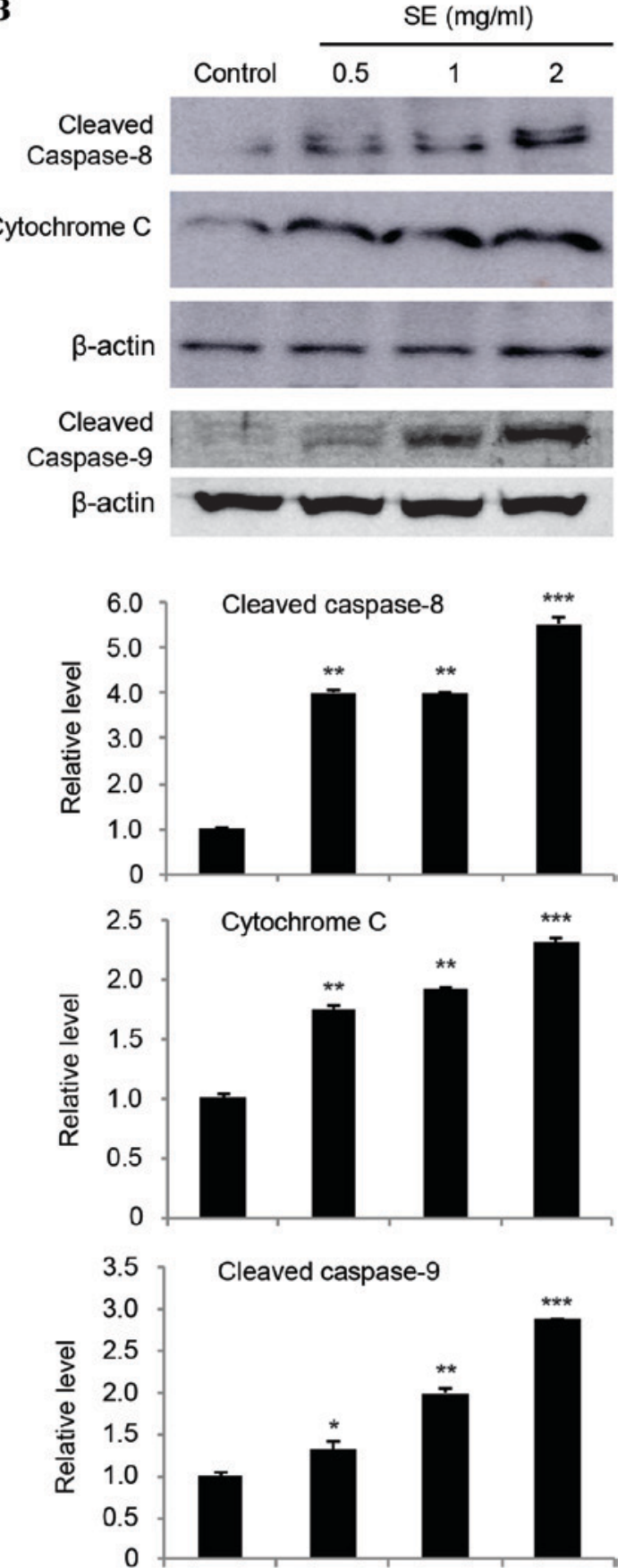

Figure 6. (A and B) Effects of SE on the expression of FADD, caspases, PARP, and cytochrome $c$ in MCF-7 cells. Cells were treated with the indicated concentrations of SE for $24 \mathrm{~h}$. Western blot analysis was performed for determination of protein levels of FADD, caspases, PARP, and cytochrome $c$. $\beta$-actin was used as a loading control. The blots included in the fig. are representative of three blots yielding similar results. The relative levels (each protein vs. $\beta$-actin) were measured via densitometry. Data present the mean \pm standard deviation from three independent experiments. ${ }^{*} \mathrm{P}<0.05,{ }^{* *} \mathrm{P}<0.01$ and ${ }^{* * * *} \mathrm{P}<0.001$ vs. control group. SE, scallop flesh extract; FADD, Fas-associated via death domain; PARP, poly (ADP-ribose) polymerase.

SE apparently induced the mitochondrial apoptotic cascade, as indicated by the decreased expression of Bcl-2, activation of Bax, release of cytochrome $c$, decrease in procaspase-3, and subsequent increase in cleaved-PARP. The expression levels of FADD and cleaved caspase-8, proteins associated with the extrinsic pathway of apoptosis, were also increased in a SE dose-dependent manner. Taken together, the data suggest that the intrinsic and extrinsic pathways are associated with the antiproliferative effects of SE on MCF-7 cells. Thus, SE may be a beneficial candidate for use in the treatment and prevention of human breast cancer. Further studies are to be conducted to confirm the anticancer effects of SE in vivo.

\section{Acknowledgements}

This study was supported by the Research Program grant funded by the National Fisheries Research and Development Institute of Korea (grant no. R2017002) and by the National Research Foundation of Korea grant from the Korean government (grant no. 2012 R1A5A2A42671316). 
A
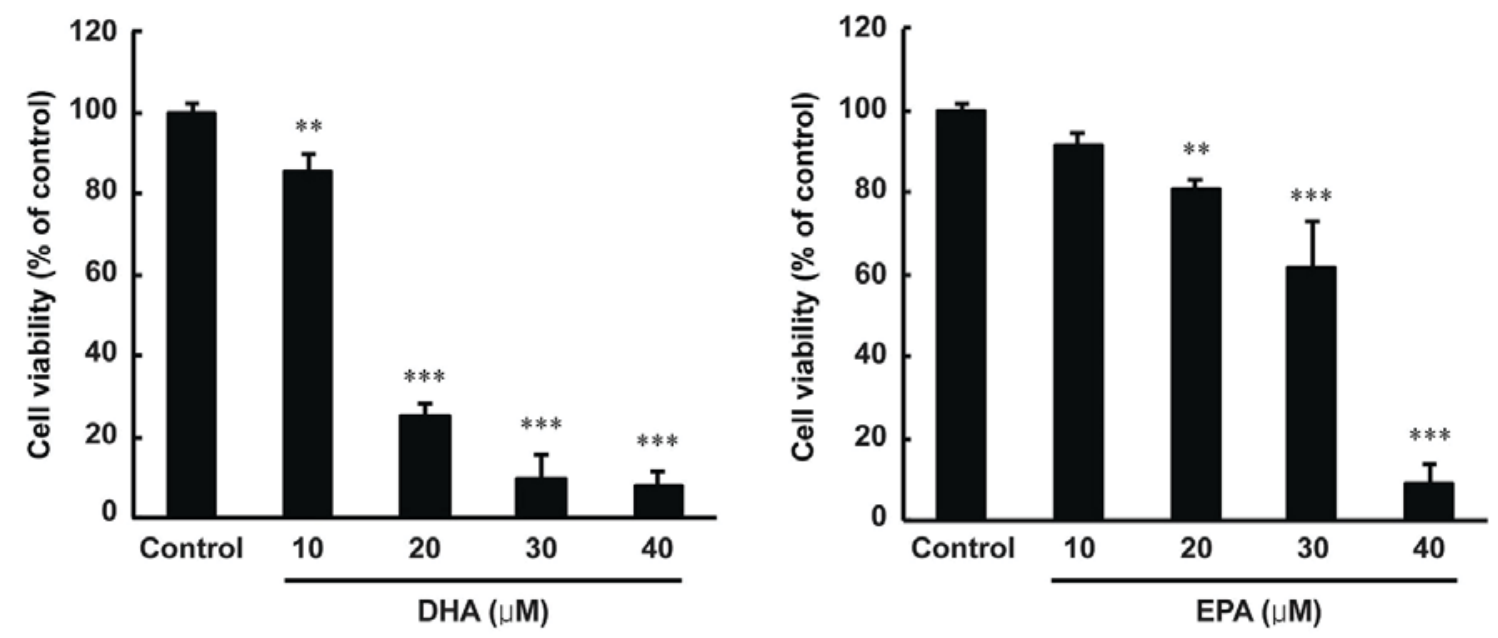

B
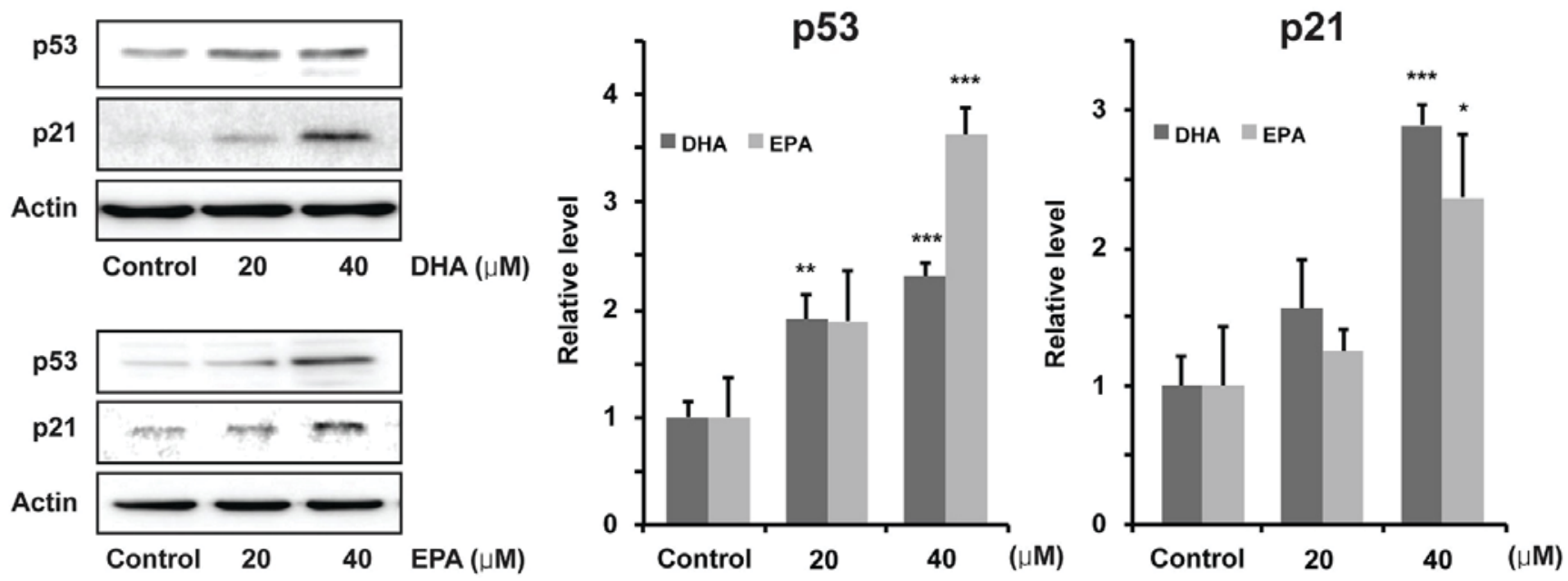

C
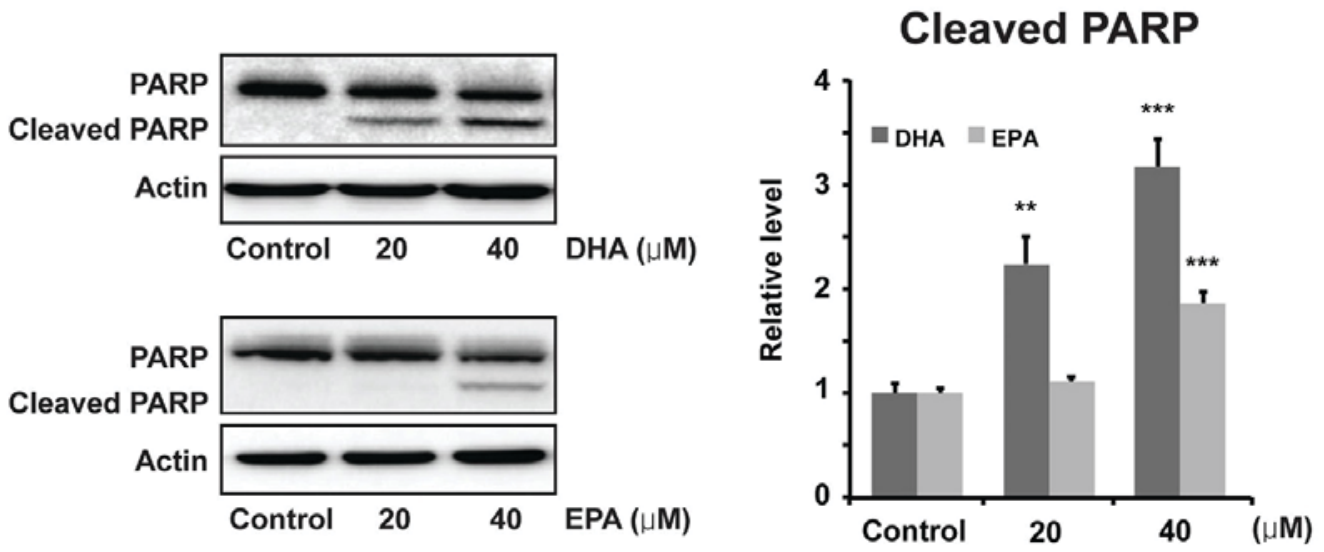

Figure 7. Effects of DHA and EPA on (A) proliferation and (B and C) protein expression levels of p53, p21 and PARP in MCF-7 cells. (A) Cytotoxic effects of DHA and EPA on MCF-7 cells $\left(2.5 \times 10^{4}\right.$ cells/well) were measured using the MTT assay. (B and C) The cells $\left(5 \times 10^{5}\right.$ cells $\left./ \mathrm{ml}\right)$ were treated with various concentrations (20 and $40 \mu \mathrm{M}$ ) of DHA and EPA for $24 \mathrm{~h}$. Western blot analysis was performed for determination of protein levels of p53, p21 and PARP. $\beta$-Actin was used as a loading control. The blots included in the fig. are representative of three blots yielding similar results. The relative levels (each protein vs. $\beta$-actin) were measured via densitometry. Data present the mean \pm SD from three independent experiments. ${ }^{*} \mathrm{P}<0.05,{ }^{* * *} \mathrm{P}<0.01$, and ${ }^{* * * *} \mathrm{P}<0.001$ vs. control group. 


\section{References}

1. Xiao PG: Atlas of Chinese Herbs. The Commercial Press Ltd. Hong Kong, vol. 7: p202, 1990

2. Nam M, Lee C, Moon TS and Huh MK: Genetic diversity and population structure of the scallop patinopecten yessoensis in Korea, China and Japan by random amplified polymorphic DNA markers. J Life Sci 22: 466-471, 2012.

3. Saad ED: Endpoints in advanced breast cancer: Methodological aspects \& clinical implications. Indian J Med Res 134: 413-418, 2011.

4. Siegel R, Ma J, Zou Z and Jemal A: Cancer statistics, 2014. CA Cancer J Clin 64: 9-29, 2014

5. Tsao AS, Kim ES and Hong WK: Chemoprevention of cancer. CA Cancer J Clin 54: 150-180, 2004.

6. Hunter T and Pines J: Cyclins and cancer II: Cyclin D and CDK inhibitors come of age. Cell 79: 573-582, 1994.

7. Harper JW and Elledge SJ: CDK inhibitors in development and cancer. Curr Opin Genet Dev 6: 56-64, 1996.

8. Sherr CJ: Cancer cell cycles. Science 274: 1672-1677, 1996.

9. Gartel AL and Tyner AL: The role of the cyclin-dependent kinase inhibitor p21 in apoptosis. Mol Cancer Ther 1: 639-649, 2002.

10. Meek DW: The p53 response to DNA damage. DNA Repair (Amst) 3: 1049-1056, 2004

11. Weng MS, Ho YS and Lin JK: Chrysin induces G1 phase cell cycle arrest in C6 glioma cells through inducing p21Waf1/Cip1 expression: Involvement of p38 mitogen-activated protein kinase. Biochem Pharmacol 69: 1815-1827, 2005.

12. Muppidi J, Porter M and Siegel RM: Measurement of apoptosis and other forms of cell death. Curr Protoc Immunol 3: 3-17, 2004

13. Evan GI and Vousden KH: Proliferation, cell cycle and apoptosis in cancer. Nature 411: 342-348, 2001.

14. MacKenzie SH and Clark AC: Targeting cell death in tumors by activating caspases. Curr Cancer Drug Targets 8: 98-109, 2008.

15. Repicky A, Jantova S and Milata V: Signal pathways of cell proliferation and death as targets of potential chemotherapeutics. Ceska Slov Farm 57: 4-10, 2008 (In Slovak).

16. Ireland CM, Copp BR, Foster MP, et al: Biomedical potential of marine natural products. In: Pharmaceutical and bioactive natural products. Attaway DH, Zaborsky OR Eds. Springer US New York, USA, vol. 1: pp1-43, 1993.

17. Lv S, Gao J, Liu T, Zhu J, Xu J, Song L, Liang J and Yu R: Purification and partial characterization of a new antitumor protein from Tegillarca granosa. Mar Drugs 13: 1466-1480, 2015

18. Sasaki T, Uchida H, Uchida NA, et al: Antitumor activity and immunomodulatory effect of glycoprotein fraction from scallop Patinopecten yessoensis. Nippon Suisan Gakkaishi 53: 267-272, 1987.

19. Zhang H, Wang K, Lin G and Zhao Z: Antitumor mechanisms of S-allyl mercaptocysteine for breast cancer therapy. BMC Complement Altern Med 14: 270, 2014.

20. Vermeulen K, Van Bockstaele DR and Berneman ZN: The cell cycle: A review of regulation, deregulation and therapeutic targets in cancer. Cell Prolif 36: 131-149, 2003.

21. Schwartz GK and Shah MA: Targeting the cell cycle: A new approach to cancer therapy. J Clin Oncol 23: 9408-9421, 2005.

22. Nagle AA, Gan FF, Jones G, So CL, Wells G and Chew EH: Induction of tumor cell death through targeting tubulin and evoking dysregulation of cell cycle regulatory proteins by multifunctional cinnamaldehydes. PLoS One 7: e50125, 2012.

23. Bellamy CO: p53 and apoptosis. Br Med Bull 53: 522-538, 1997.

24. Levine AJ: p53, the cellular gatekeeper for growth and division. Cell 88: 323-331, 1997.

25. Pucci B, Kasten M and Giordano A: Cell cycle and apoptosis. Neoplasia 2: 291-299, 2000 .

26. Harris SL and Levine AJ: The p53 pathway: Positive and negative feedback loops. Oncogene 24: 2899-2908, 2005.

27. Didenko VV, Wang X, Yang L and Hornsby PJ: Expression of p21(WAF1/CIP1/SDI1) and p53 in apoptotic cells in the adrenal cortex and induction by ischemia/reperfusion injury. J Clin Invest 97: 1723-1731, 1996.

28. Yang L, Zhang HW, Hu R, Yang Y, Qi Q, Lu N, Liu W, Chu YY, You QD and Guo QL: Wogonin induces G1 phase arrest through inhibiting CDK4 and cyclin D1 concomitant with an elevation in p21Cip1 in human cervical carcinoma HeLa cells. Biochem Cell Biol 87: 933-942, 2009.

29. Zorn JA, Wolan DW, Agard NJ and Wells JA: Fibrils colocalize caspase-3 with procaspase-3 to foster maturation. J Biol Chem 287: 33781-33795, 2012.
30. Donepudi M and Grütter MG: Structure and zymogen activation of caspases. Biophys Chem 101-102: 145-153, 2002.

31. Stennicke HR and Salvesen GS: Caspases. Controlling intracellular signals by protease zymogen activation. Biochim Biophys Acta 1477: 299-306, 2000

32. Gray DC, Mahrus S and Wells JA: Activation of specific apoptotic caspases with an engineered small molecule-activated protease. Cell 142: 637-646, 2010.

33. Putt KS, Chen GW, Pearson JM, Sandhorst JS, Hoagland MS, Kwon JT, Hwang SK, Jin H, Churchwell MI, Cho MH, et al: Small-molecule activation of procaspase-3 to caspase-3 as a personalized anticancer strategy. Nat Chem Biol 2: 543-550, 2006.

34. Fulda S and Debatin KM: Extrinsic versus intrinsic apoptosis pathways in anticancer chemotherapy. Oncogene 25: 4798-4811, 2006.

35. Salvesen GS and Riedl SJ: Caspase mechanisms. Adv Exp Med Biol 615: 13-23, 2008

36. Mcllwain DR, Berger T and Mak TW: Caspase functions in cell death and disease. Cold Spring Harb Perspect Biol 5: a008656, 2013

37. Kroemer G and Reed JC: Mitochondrial control of cell death. Nat Med 6: 513-519, 2000.

38. Gross A, McDonnell JM and Korsmeyer SJ: Bcl-2 family members and the mitochondria in apoptosis. Genes Dev 13: 1899-1911, 1999.

39. Li H, Wang LJ, Qiu GF, Yu JQ, Liang SC and Hu XM: Apoptosis of Hela cells induced by extract from Cremanthodium humile. Food Chem Toxicol 45: 2040-2046, 2007.

40. Elmore S: Apoptosis: A review of programmed cell death. Toxicol Pathol 35: 495-516, 2007.

41. Nagata S: Apoptosis by death factor. Cell 88: 355-365, 1997.

42. Schwartsmann G, Brondani da Rocha A, Berlinck RG and Jimeno J: Marine organisms as a source of new anticancer agents. Lancet Oncol 2: 221-225, 2001.

43. Mitsiades CS, Ocio EM, Pandiella A, Maiso P, Gajate C, Garayoa M, Vilanova D, Montero JC, Mitsiades N, McMullan CJ, et al: Aplidin, a marine organism-derived compound with potent antimyeloma activity in vitro and in vivo. Cancer Res 68: 5216-5225, 2008.

44. Suarez-Jimenez GM, Burgos-Hernandez A and Ezquerra-Brauer JM: Bioactive peptides and depsipeptides with anticancer potential: Sources from marine animals. Mar Drugs 10: 963-986, 2012.

45. Chapkin RS, Seo J, McMurray DN and Lupton JR: Mechanisms by which docosahexaenoic acid and related fatty acids reduce colon cancer risk and inflammatory disorders of the intestine. Chem Phys Lipids 153: 14-23, 2008.

46. Fukui M, Kang KS, Okada K and Zhu BT: EPA, an omega-3 fatty acid, induces apoptosis in human pancreatic cancer cells: Role of ROS accumulation, caspase- 8 activation, and autophagy induction. J Cell Biochem 114: 192-203, 2013.

47. Maleek MI: Omega-3 fatty acids decrease the proliferation of Rhabdomyosarcoma (RD) and Vero cell lines. J Cancer Sci Ther 5: 85-88, 2013.

48. Park JM, Kwon SH, Han YM, Hahm KB and Kim EH: Omega-3 polyunsaturated fatty acids as potential chemopreventive agent for gastrointestinal cancer. J Cancer Prev 18: 201-208, 2013.

49. Yang P, Cartwright C, Chan D, Ding J, Felix E, Pan Y, Pang J, Rhea P, Block K, Fischer SM, et al: Anticancer activity of fish oils against human lung cancer is associated with changes in formation of PGE2 and PGE3 and alteration of Akt phosphorylation. Mol Carcinog 53: 566-577, 2014

50. Kato T, Hancock RL, Mohammadpour H, McGregor B, Manalo P, Khaiboullina S, Hall MR, Pardini L and Pardini RS: Influence of omega-3 fatty acids on the growth of human colon carcinoma in nude mice. Cancer Lett 187: 169-177, 2002.

51. Wu M, Harvey KA, Ruzmetov N, Welch ZR, Sech L, Jackson K, Stillwell W, Zaloga GP and Siddiqui RA: Omega-3 polyunsaturated fatty acids attenuate breast cancer growth through activation of a neutral sphingomyelinase-mediated pathway. Int J Cancer 117: 340-348, 2005.

52. Shaikh IA, Brown I, Schofield AC, Wahle KW and Heys SD: Docosahexaenoic acid enhances the efficacy of docetaxel in prostate cancer cells by modulation of apoptosis: The role of genes associated with the NF-kappaB pathway. Prostate 68: 1635-1646, 2008

53. Hawcroft G, Volpato M, Marston G, Ingram N, Perry SL, Cockbain AJ, Race AD, Munarini A, Belluzzi A, Loadman PM, et al: The omega-3 polyunsaturated fatty acid eicosapentaenoic acid inhibits mouse MC-26 colorectal cancer cell liver metastasis via inhibition of PGE2-dependent cell motility. Br J Pharmacol 166: 1724-1737, 2012. 